\title{
Capacity Optimization Study of Chua Mini-Hydropower Plant at Chua River, Manica, Mozambique
}

\author{
Miguel M. Uamusse $^{1,2}$, Alberto J. Tsamba ${ }^{2}$, Jonas Matsinhe' ${ }^{2}$, Kenneth M. Persson ${ }^{1}$ \\ ${ }^{1}$ Department of Water Resource Engineering, Lund University, Lund, Sweden \\ ${ }^{2}$ Department of Chemical Engineering, Eduardo Mondlane University, Maputo, Mozambique \\ Email: miguel.meque@uem.mz
}

Received 10 October 2015; accepted 28 December 2015; published 31 December 2015

Copyright $(\underset{2015}{ }$ by authors and Scientific Research Publishing Inc.

This work is licensed under the Creative Commons Attribution International License (CC BY). http://creativecommons.org/licenses/by/4.0/

(c) (i) Open Access

\begin{abstract}
Hydropower energy is one of most promising clean energy technologies, however this energy technology has many challenges. Compared with other renewable energies for example biomass, solar and wind energies, it has high capital investment cost. In Mozambique, access to conversional energy in form of electricity has been limited to most of the rural population. The objectives of the investigation research are to analyze Chua micro-hydropower plant exploration in Manica district in Mozambique and to examine the possibility of increasing energy production. The current total installed power generation capacity in Mozambique is about 939 MW. Hydropower contributes $561 \mathrm{MW}$, making a contribution of $61 \%$. Oil contributes $27 \%$, and natural gas contributes $12 \%$ of the total electric grid generation in Mozambique.
\end{abstract}

\section{Keywords}

Hydropower, Renewable Energy, Manica, Mozambique

\section{Introduction}

According current energy crisis, energy is considered as a key in generation of health, social development and improved quality of life in all developing countries in the world. Produced and consumed energy resources and especially renewable energy sources in particularly hydropower have very important value to increase energy demand in national grid. Some district and other rural localities with high population concentrations have not yet supplied with electricity and still have old generation (Diesel plant) and distribution systems that are no longer functioning; approximately $13.3 \%$ has access to electricity. Small hydropower can be one of the solutions to in- 
crease electrification in Mozambique and combat poverty in rural areas [1]-[5].

The conventional energy from EDM grid currently only reaches $22 \%$ of the population, over half those having access being in and around Maputo, with all provincial capitals and most urban centres connected, giving access of $27 \%$ in urban areas and $6 \%$ in rural areas. People not on the grid are mainly those living in peri-urban areas, district capitals and rural areas [2] [3].

Hydropower energy is the most effective source of energy and electricity and has played a major role in the development of modern civilization and hydropower energy is a kind of renewable energy that comes from moving water and converts into electricity. Hydropower technology has some benefits than fossil fuel; it is a renewable source of energy with no emissions of carbon dioxide in comparison to other forms of energy and fossil fuel. In addition, hydropower projects can be used for multipurpose use, such as irrigation, fishery, flood control and water supply and getting access to modern energy services which are fundamental in fulfilling basic social needs and driving economic growth, as well as have an effect on productivity, health, education, safe water and communication services [6]-[12].

Energy from Hydropower according to [12] is powerful resource that has potential to catalyze social to change standard living by providing opportunities for new range of activities to improve quality of life for rural population. According [12] [13], the Hydropower energy source in power generation was $15.3 \%$ in 2011 and the largest share in global generation scenario was from fossil fuel and nuclear which were contributing $77.9 \%$, followed by other renewable energies which were 5\%. The fossil fuel in Figure 1 refers dominant source of energy for electricity generation.

The totally hydropower energy generation capacity in the world has been increasing steadily over the last 50 years, and has shown an increased rate in the past few years. Table 1 shows regional hydropower characteristics in terms of hydropower in operation, under construction and in the plan [12]-[14].

\subsection{Currently Renewable Energy Outlook in Mozambique}

The hydropower potential in Mozambique is attractive with hydropower potential estimated to 12,000 MW of which only roughly 2200 MW has been develop to access the national grid, the government of Mozambique has placed rural electrification as a major component of its development programs to meet demand. Furthermore, Mozambique has liberalized its energy sector and allowed inflow of foreign direct investment into hydro projects. The government of Mozambique has adopted a number of broad policy objectives relating to the Development and governance of the energy sector. The government bears the responsibility of rural electrification in terms of creating an enabling environment for all stakeholders [14]-[16]. Development of Renewable energy in Mozambique dates back during the colonial period where hydropower plants were developed to supply power to large urban city like Maputo, Beira and Nampula and even to some part of energy for selling to South Africa. The total energy mix installed in Mozambique according [15] [16] was 408.9 PJ and it can see that Hydropower is $13 \%$, biomass $78 \%, 7 \%$ Oil product and other resources $2 \%$.

According [4]-[10] government together with its partners organization they mapped and assess hydropower potential and the result has shown Mozambique has greatest potential lies in the Zambezi River basin at sites such as Cahora Bassa North and MphandaNkuwa is about 2,200 MW of generating capacity .The total hydropower currently exploration is presented in Table 2. The most important Hydropower plant is Cahora Bassa with $95 \%$ of total contribution.

Table 1. Comparison of the global hydropower plant.

\begin{tabular}{cccc}
\hline Continent & Hydropower operation-[MW] & Hydropower under construction-[MW] & Hydropower planed-[MW] \\
\hline Africa & 23,428 & 5222 & 76,600 \\
Asia & 401,626 & 125,736 & 141,300 \\
Europe & 197,152 & 3028 & 11,400 \\
America & 169,105 & 7798 & 17,400 \\
South of America & 139,424 & 19,555 & 57,300 \\
Australia & 13,370 & 67 & 1500 \\
Total & 926,159 & 161,400 & 305,500 \\
\hline
\end{tabular}




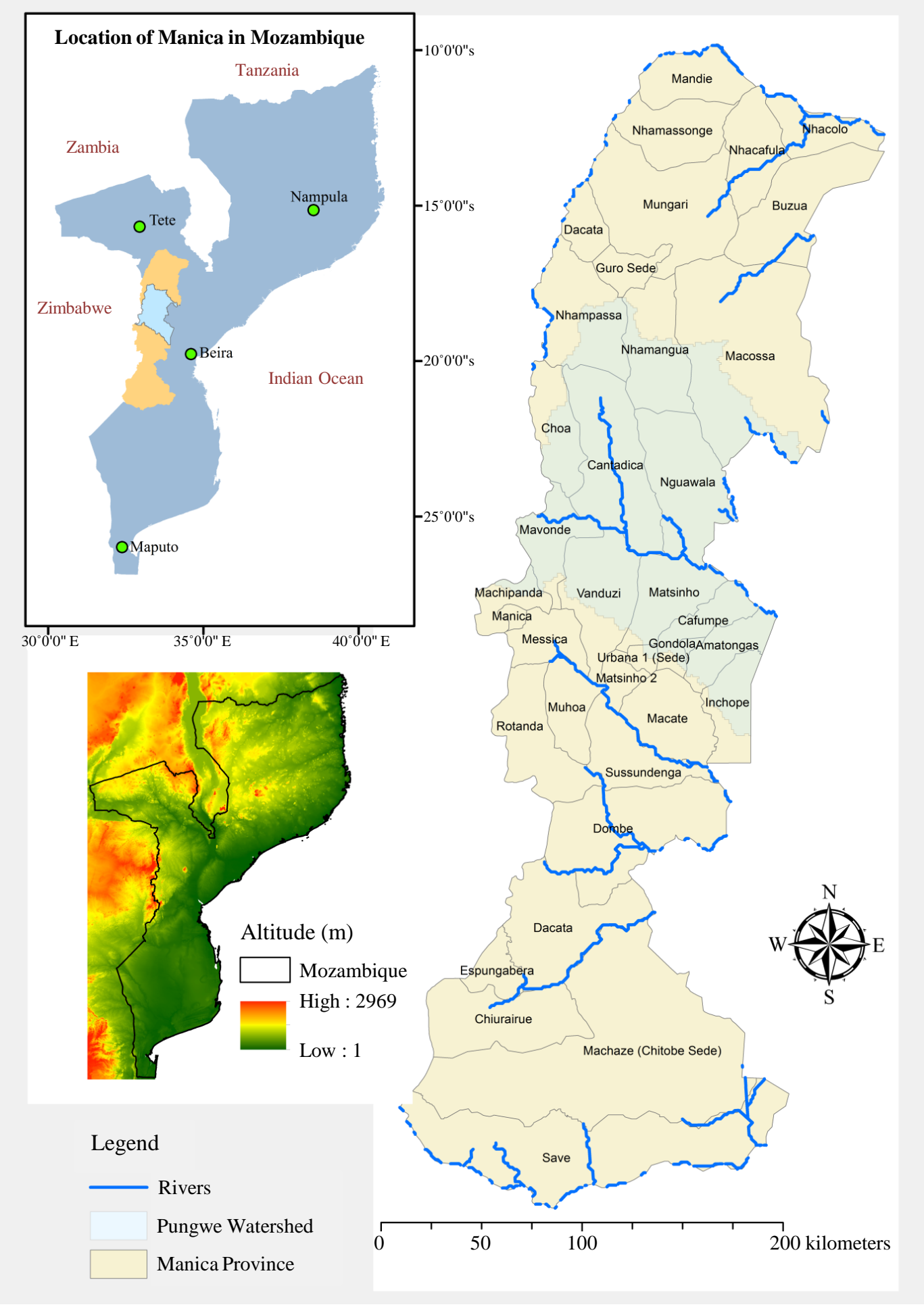

Figure 1. Manica Province in Mozambique.

In recent years, the government of Mozambique faced with increasing population that already about 25 millions and with increasing investment sees the need to increase energy demand for local consumption, and building investment was identified about 80 hydropower potential sites and mostly in Central region of Mozambique (Manica and Tete) see Table 3. 
Table 2. Mozambique hydropower currently exploration.

\begin{tabular}{cccc}
\hline Hydropower Plant & Province & River & Capacity (MW) \\
\hline Cabora Bassa & Tete & Zambeze & 2075.0 \\
Mavuzi & Manica & Rivue & 42.0 \\
Chicamba & Manica & Rivue & 38.0 \\
Corumana & Maputo & Sabie & 16.0 \\
Cuamba & Niassa & & 1.0 \\
Lichinga & Niassa & & 0.75 \\
\hline
\end{tabular}

Table 3. Mozambique hydropower estimated potential site.

\begin{tabular}{cccc}
\hline Number & Project & Capacity (MW) & Province \\
1 & Cabora Bassa North & 2200 & Tete \\
2 & Tsatse & 50 & Zambezia \\
3 & Muenezi & 25 & 40 \\
4 & Alto Molocue & 175 & Manica \\
5 & Mugebe & 180 & Manica \\
7 & Lucite & 300 & Manica \\
9 & Buzi-Miracuene & 50 & Sofala \\
10 & Pungwe-Pávue & 80 & Niassa \\
12 & Pungwe-Bue Maria & 10 & Gaza \\
& Mavuzi & 600 & 60 \\
\end{tabular}

\subsection{Classification of Hydropower in Mozambique}

Hydropower government categorize in many different ways because there is no common classification, some of the methods of classification are based on amount of electricity is generated by the plant, what kind of grid system is utilized for the distribution of electricity, the type of load capacity and the type of storage used by the system. In Mozambique is categorized into large scale ( $>30 \mathrm{MW})$, micro power plant ( $<100 \mathrm{~kW})$, mini power plant $(100<\mathrm{kW}<500 \mathrm{~kW})$ and small Hydropower plant $(2.0<\mathrm{MW}<8.0)$. While storage scheme based in small hydro power plants they can be classified into storage type, run-of-the-river type or by use of existing water supply [5] [17].

\section{Study Area of Chua in Manica}

The history of hydropower development activity in Manica dates back during the colonial period where small scale hydropower plants was developed to supply water, electricity to specific communities in Chua Manica. Before this Hydro power plant was use to grind food (rice, maize) as shown in the Figure 1. In the late 1990s with peace in Mozambique begins development decade in Manica district, and the Germany organization GIZ, modernized the system used for corn milling, turning into a hybrido system to production electricity of approximately 50 families including school and hospital. Manica is in central of Mozambique see Figure 1 and covers approximately $7500 \mathrm{~km}^{2}$. The population of Manica Province 2015 is about 1,438,476 with a seasonal wet-dry climate and $1090 \mathrm{~mm}$ rain per year.

\subsection{Hydropower Activity in Manica}

Manica has substantial potential of small hydropower and in this district the business of renewable energies is 
traditional, it is a normal activity, with support by GIZ Germany organization and FUNAE, some Hydropower plant as shown by Table 4 .

\section{Methodology}

For the purpose of this article, one scientific challenge is to analyze the old plant, and to achieve the above research, different methods have been used to meet the specific objectives of this paper. The following activities were carried out, literature search and assessment of hydropower potential, design and selection Pelton turbine machine.

\subsection{Literature Review}

In order to have a better understanding and obtain useful information in the research area, various literatures in hydropower, small hydropower development and past research in this research area and the existing turbines for mini hydro reviewed.

\subsection{Hydrological Correlation Analysis}

To estimate the flow, analysis was made by utilizing the available historical flow data records from a nearby gauging station on the Chua River. A set of historical flow data recorded for 39 years dated from 1954 to 2004 were used Wavelet neural network model (WNN). The time series of the collected data sample for a period of 48 years was plotted. Equation (1) and Equation (2) were computed to check if gauged points are correlated WNN method and forecasting Models search as Coefficient of correlation and root mean square error are used [18]-[22].

$$
\begin{gathered}
R^{2}=1-\frac{\sum_{1}^{n}\left(Q_{\text {measured }}-Q_{\text {predicted }}\right)^{2}}{\sum_{1}^{1}\left(Q_{\text {measured }}-Q_{\text {mean }}\right)^{2}} \\
R M S E=\sqrt{\frac{\sum_{1}^{n}\left(Q_{\text {measered }}-Q_{\text {predicted }}\right)^{2}}{n}}
\end{gathered}
$$

where: $Q$ is flow in $\mathrm{m}^{3} / \mathrm{s}$.

Table 4. Manica small hydropower currently exploration.

\begin{tabular}{cccc}
\hline Site location & Discharge $\left(\mathbf{m}^{3} / \mathbf{s}\right)$ & Capacity $\mathbf{( k W )}$ & Purpose \\
\hline Chua Lino & 0.11 & 22 & Electricity, Gridding mill \\
Chua Mucheca & 0.10 & 18 & Electricity, Gridding mill, irrigation \\
Chua-Gim & 0.11 & 18 & Electricity, Gridding mill \\
Chua-Nguarani & 0.08 & 22 & Electricity, Gridding mill \\
Chimucono & 0.11 & 26 & Electricity, Gridding mill, irrigation \\
Ganhira & 0.3 & 16 & Electricity, Gridding mill, Irrigation \\
Mangunda & 0.1 & 26 & Electricity, Gridding mill \\
Mudododo I & 0.2 & 16 & Electricity, Gridding mill, irrigation \\
Mudododo II & 0.18 & 16 & Electricity, Gridding mill \\
Mussapa & 0.25 & 20 & Electricity, Gridding mill \\
Nhancurara & 0.10 & 26 & Electricity, Gridding mill, irrigation
\end{tabular}




\subsection{Turbine Dimension}

For the purpose of dimensions of turbine the following formulas are used for various parameters. The parameters are power, runner diameter, jet velocity, area of the jet, jet width, blade radius.

\subsection{Power Demand}

Hydropower schemes use kinetic energy of moving water to produce electricity. The amount of electricity produced by turbine is determine by the water flow rate and vertical fall of water from upstream level to downstream level called the Head see the equation [18] [23]-[28]. The turbine old and projected a shown in Figure 2.

$$
P=\rho g H Q \eta
$$

where: $P$, mechanical power produced at the turbine shaft; $\rho$ is density of water $\left(\mathrm{kg} / \mathrm{m}^{3}\right)$; $Q$, flow rate passing through the turbine $\left(\mathrm{m}^{3} / \mathrm{s}\right) ; \eta$, hydraulic efficiency of the turbine; $H$, the effective pressure head of water across the turbine $(\mathrm{m})$.

\subsection{Turbine Runner Diameter ( $\left.D_{\text {runner }}\right)$, Jet Velocity ( $V$ ) Area of Jet $\left(A_{j}\right)$ and Number of Blades $(N)$}

\subsubsection{Turbine Runner Diameter}

$$
D_{\text {runner }}=\frac{40 \sqrt{H}}{N}
$$

\subsubsection{Specific Speed}

$$
N_{s}=\frac{N \sqrt{Q}}{H^{0.75}} \text { and } N=\frac{N_{s} \times H^{0.75}}{\sqrt{Q}}
$$

\subsubsection{Jet Velocity and Area of the Jet}

$$
V=C d \sqrt{2 g H} \text { and } A_{j e t}=\frac{Q}{V}
$$

\subsubsection{Number of Blades}

$$
n=\frac{\pi D}{t+t_{j e t}}
$$

where: $D$ is the diameter of the runner, $H$ is net head, $N$ is speed of the runner in revolution per minutes, $N_{s}$ is the specific speed, $Q$ is the volume flow rate $\left(\mathrm{m}^{3} / \mathrm{s}\right), C_{d}$ is coefficient of discharge and $V$ is velocity in $\mathrm{m} / \mathrm{s}$. For this design, $N_{s}=30$ was select.

\section{Results and Discussions}

This section of paper presents the results and findings of the study and accordingly interprets the methodology. All calculations computed from the formulae which were discussed and presented in the proceeding and reference to the appropriate formulae were made accordingly with respect to every result. Some data collected helped to the success of this Article as $\eta=80 \%, Q=0.15 \mathrm{~m}^{3} / \mathrm{s}, H=48 \mathrm{~m}$, Assumed $N_{s}=25 \mathrm{rpm}$. Based on the analyses, the turbine dimension is shown in Table 5. However, the plant's capacity has $34.220 \mathrm{~kW}$; therefore, the power can be supplied to few houses including Chua village hospital and primary school.

\subsection{Turbine Selection}

Since the net head of the mini hydropower system at Chua stream is $48 \mathrm{~m}$ and the design discharge is $0.15 \mathrm{~m}^{3} / \mathrm{s}$, from turbine chart, Figure 3, the appropriate turbine for this scheme is Pelton with efficiency of $80 \%$ - 

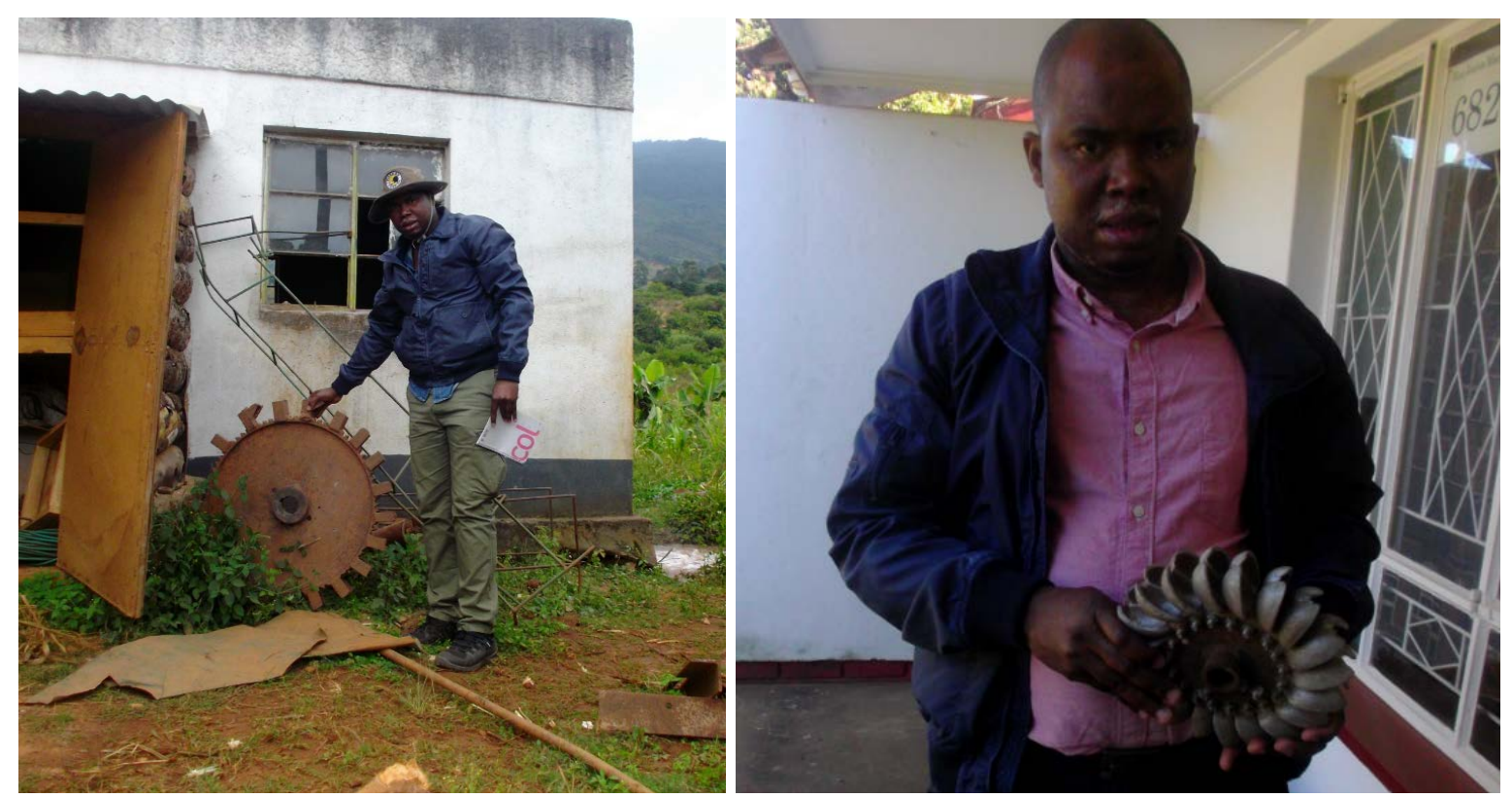

Figure 2. Old turbine (a) and new projected turbine (b).

Table 5. Manica small hydropower currently exploration.

\begin{tabular}{ccc}
\hline Parameter & Result & Unit \\
$P$ & 34.220 & $\mathrm{~kW}$ \\
$N$ & 1649.51 & $\mathrm{rpm}$ \\
$N_{s}$ & $* 30$ & $\mathrm{rpm}$ \\
Drunner & 168 & $\mathrm{~mm}$ \\
$n$ & 15 & Blades \\
$A_{\text {ject }}$ & 0.0049 & $\mathrm{~m}^{2}$ \\
$V_{\text {ject }}$ & 30.36 & $\mathrm{~m} / \mathrm{s}$ \\
\hline
\end{tabular}

$90 \%$ whose rated power capacity is $34.220 \mathrm{~kW}$.

\subsection{Hydrological Correlation Analysis Discussion}

To estimate the flow, analysis was made by utilizing the available historical flow data records from a nearby gauging station on the Chua River. A set of historical flow data recorded for 39 years dated from 1956 to 2004 were used Wavelet neural network model. The time series of the collected data sample for a period of 48 years plotted. Moreover, to assess the performance of model we find training and validation coefficient of correlations is $\left(R^{2}\right)$ is 0.9031 and 0.89 in Figure 4, while the root mean square error is (RMSE) is 258 and 176.4 and NSE is 0.771 and 0.72 .

\section{Conclusion}

This study was carried out with the aim of capacity optimization study of Chua mini-hydropower plant at Chua River in Manica, Mozambique where a hydropower was used for milling corn other cereals. After this study, we can see that it is possible to increase power demand in Chua hydropower plant to $34 \mathrm{~kW}$ and that the power demand of the village can increase. Success refurbishing or upgrading of a small-scale hydropower schemes will create job opportunities during the good operation, as well as provide energy to households and promote some economic activities such as trade and irrigation. 


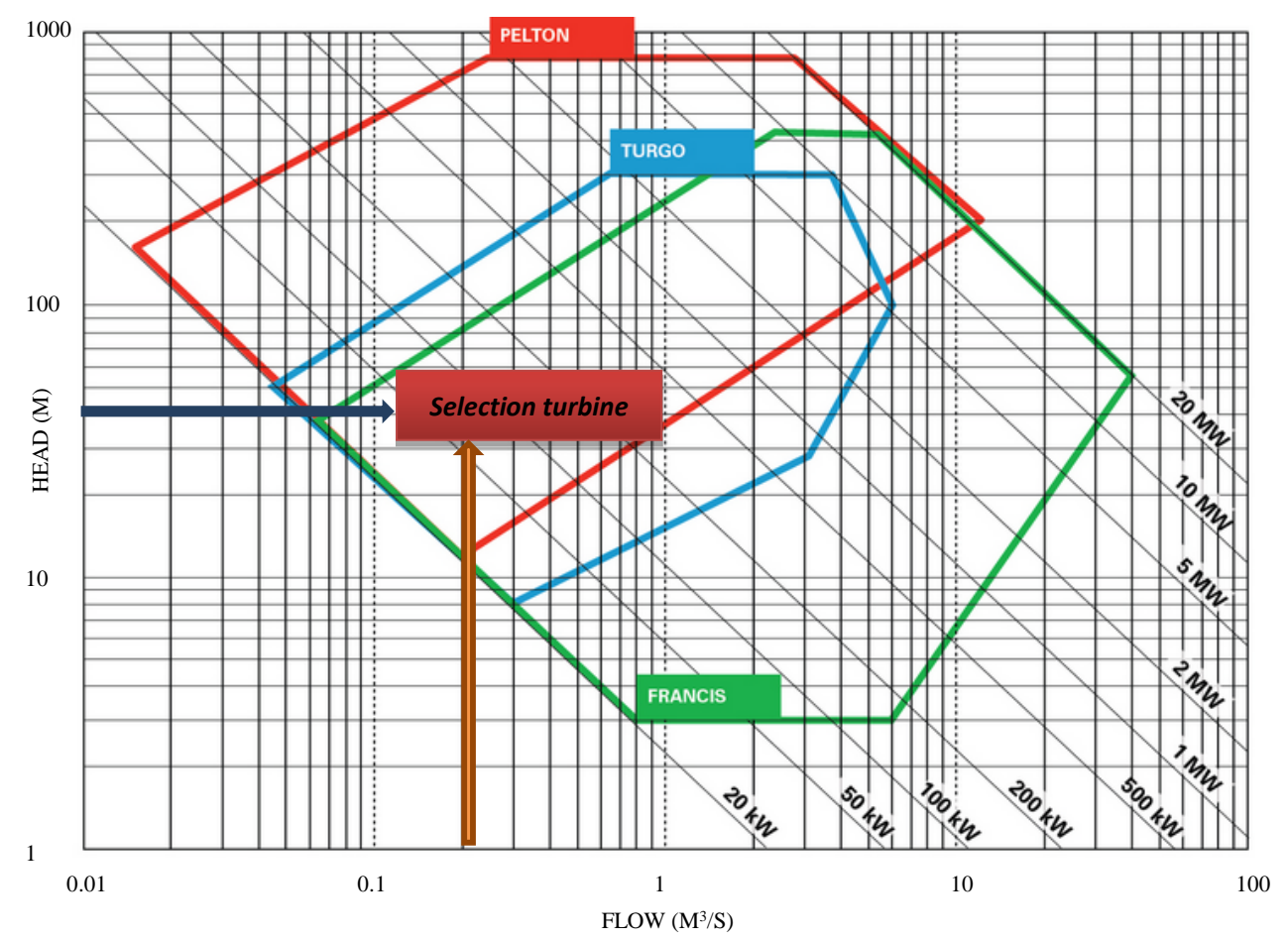

Figure 3. Turbine selection, adapted in this source: http://www.gilkes.com/Turbine-Selection (01/09/ 2015).

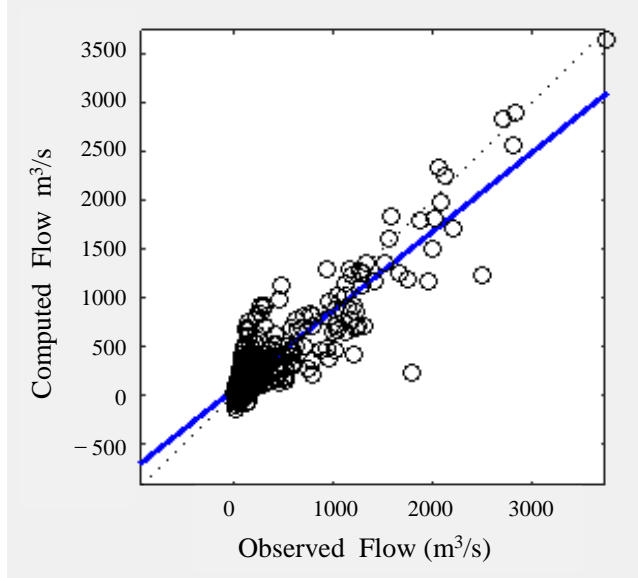

Figure 4. Scatter plot between an observed validation flow.

\section{Acknowledgements}

We would like to express our sincere gratitude to our supervisors, Lund University and Eduardo Mondlane University. The support was provided throughout the entire period of our investigation.

\section{References}

[1] Ministry of Energy (2011) Electricity Reform Access Programme Mozambique.

[2] EDM (Electricidad de Mocambique) (2011) Stastitical Summary. http://www.edm.co.moz/

[3] IEA (2009) IEA Energy Statistics—Energy Balances for Mozambique. http://www.iea.org/stats/balancetable.asp

[4] Mahumane, G., Mulder, P., Oçambique, M., Cumulação, A., Ransformação, Em, E.T., Ontexto, C. and Rise, D.E.C. (2012) Energy Outlook for Mozambique 2012-2030 LEAP-Based Scenarios for Energy Demand and Power Genera- 
tion. In III CONFERÊNCIA INTERNACIONAL DO IESE, 31.

http://www.iese.ac.mz/lib/publication/III_Conf2012/IESE_IIIConf_Paper16.pdf

[5] Chambal, H. (2010) Energy Security in Mozambique. Policy Report 3. Series on Trade and Energy Security. International Institute for Sustainable Development (IISD), Maputo.

[6] Cuamba, Chongo, B., dos Santos Cipriano, A., Henrique, R. and Turatsinze, J. (2013) Investment Incentives for Renewable Energy in Southern Africa: The Case of Mozambique. Trade Knowledge Network. International Institute for Sustainable Development (IISD), Maputo.

[7] Uamusse, M., Persson, K. and Tsamba, A. (2014) Gasification of Cashew Nut Shell Using Gasifier Stove in Mozambique. Journal of Power and Energy Engineering, 2, 11-18. http://dx.doi.org/10.4236/jpee.2014.27002

[8] Macaringue, D. (2009) The Potential for Micro-Hydro Power Plants in Mozambique. Literature Review and Project Proposal. University of KwaZulu-Natal, Pietermaritzburg.

[9] Cuamba, B.C., Uthui, R., Chenene, M.L., et al. (Unpubl.) Identification of Areas with Likely Good Wind Regimes for Energy Applications in Mozambique. Eduardo Mondlane University, Maputo

[10] REN21 (2015) Renewables Interactive Map Country Profile: Mozambique. Renewable Energy Policy Network for the 21st Century. http://www.map.ren21.net/Mozambique_Renewables_Profile

[11] Ahlborga, H. and Sjöstedt, M. (2015) Small-Scale Hydropower in Africa: Socio-Technical Designs for Renewable Energy in Tanzanian Villages. Energy Research \& Social Science, 5, 20-33. http://dx.doi.org/10.1016/j.erss.2014.12.017

[12] Kaunda, C.S., Kimambo, C.Z. and Nielsen, T.K. (2012) Hydropower in the Context of Sustainable Energy Supply: A Review of Technologies and Challenges. ISRN Renewable Energy, 2012, Article ID: 730631. http://dx.doi.org/10.5402/2012/730631

[13] Sadati, S.M.S., Qureshi, F.U. and Baker, D. (2015) Energetic and Economic Performance Analyses of Photovoltaic, Parabolic Trough Collector and Wind Energy Systems for Multan, Pakistan. Renewable and Sustainable Energy Reviews, 47, 844-855. http://dx.doi.org/10.1016/j.rser.2015.03.084

[14] Bartle, A. (2010) Hydropower and Dams, World Atlas. Aqua Media International Ltd., Sutton.

Lehner, B., Czisch, G. and Vassolo, S. (2005) The Impact of Global Change on the Hydropower Potential of Europe: A Model-Based Analysis. Energy Policy, 33, 839-855. http://dx.doi.org/10.1016/j.enpol.2003.10.018

[15] IEA (2011) World Energy Outlook: Access to Electricity. http://www.iea.org/weo/electricity.asp

[16] IRENA (2012) Mozambique RRA Preliminary Findings. http://www.irena.org/DocumentDownloads/Publications/RRA_Mozambique_English.pdf

[17] Kosnik, L. (2010) The Potential for Small Scale Hydropower Development in the US. Energy Policy, 38, 5512-5519. http://dx.doi.org/10.1016/j.enpol.2010.04.049

[18] Yuksel, I. (2010) As a Renewable Energy Hydropower for Sustainable Development in Turkey. Renewable and Sustainable Energy Reviews, 14, 3213-3219. http://dx.doi.org/10.1016/j.rser.2010.07.056

[19] Nourani, V., Hosseini, A., Adamowski, J. and Kisi, O. (2014) Applications of Hybrid Wavelet-Artificial Intelligence Models in hydrology: A Review. Journal of Hydrology, 514, 358-377. http://dx.doi.org/10.1016/j.jhydrol.2014.03.057

[20] Partal, T. and Kisi, Ö. (2007) Wavelet and Neuro-Fuzzy Conjunction Model for Precipitation Forecasting. Journal of Hydrology, 342, 199-212. http://dx.doi.org/10.1016/j.jhydrol.2007.05.026

[21] Li, G., Sun, Y.J., He, Y., Li, X.F. and Tu, Q.Y. (2014) Short-Term Power Generation Energy Forecasting Model for Small Hydropower Stations Using GA-SVM. Mathematical Problems in Engineering, 2014, Article ID: 381387. http://dx.doi.org/10.1155/2014/381387

[22] Mohammadi, K., Eslami, H. and Kahawita, V. (2006) Parameter Estimation of an ARMA Model for River Flow Forecasting Using Goal Programming. Journal of Hydrology, 331, 293-299. http://dx.doi.org/10.1016/j.jhydrol.2006.05.017

[23] DOE (2009) Manual and Guidelines for Micro-Hydropower Development in Rular Electrification Volume I. JICA.

[24] ESHA (2004) Guide on How to Develop a Small Hydropower Plant. European Small Hydropower Association.

[25] Montanari, R. (2003) Criteria for the Economic Planning of a Low Power Hydroelectric Plant. Renewable Energy, 28, 2129-2145. http://dx.doi.org/10.1016/S0960-1481(03)00063-6

[26] Hall, D.G., Carroll, G.R., Cherry, S.J., Lee, R.D. and Sommers, G.L. (2002) Low Head/Low Power Hydropower Resources Assessment of the Arkansas White Red Hydrologic Region. DOE/ID-11019.

[27] Yaakob, O.B., Ahmed Yasser, M., Elbatran, A.H. and Shabara, H.M. (2014) A Review on Micro Hydro Gravitational Vortex Power and Turbine Systems. Jurnal Teknologi, 69, 7. http://dx.doi.org/10.11113/jt.v69.3259

[28] IHA (2003) The Role of Hydropower in Sustainable Development. International Hydropower Association, IHA White Paper, 1-140. 